newsletter. Even though the largest part of Serbian cultural and political elites appeared to trust them and publically demonstrated their loyalty to them, radicals, who came to power with the help of Budapest, continued the attacks. It was absurd that they, who managed the funds and contributed to its weakening, demagogically accused the Serbian patriarch for that, even though he was not involved. It was done by disclosing the long forgotten Branković's financial affairs. The author states that, no matter how small the affairs were, they could not benefit the patriarch, but that it had to be taken into consideration what the Primate spent his money on, which he had received by virtue of his position. Ass. Prof. Vasin further elaborates this in the next chapter, concluding this one with the observations of contemporaries - that radicals of Jaša Tomić contributed to the downfall of Serbian autonomy and paralyzed it to that extent that the country had no difficulty to abolish it in 1912 in the context of other external and internal political developments. At the same time, their constant demagogical and sensationalistic writing in the negative tone about the Serbian Patriarch contributed to the damage of the reputation of one of the most important Serbian institutions - The Diocese of Karlovac, and to one of the most important metropolitan positions - the Patriarch.

Patriarch Georgije Branković did not leave a significant mark just on the Serbian political scene; on the contrary, what linked his name to the Serbian politics had long been forgotten, the clue about it remained only in the references and literature, the most significant example being this book. Even today, constructions that had been built thanks to his financial means could be seen. Ass. Prof. Goran Vasin dedicates a special chapter to that (Patron, 261-317), where he counts not only the constructions that had been raised, but also all the monasteries which the Patriarch helped. The chapter then points to the special care that the Patriarch dedicated to education or funds. His contribution to this field, which was testified by his contemporaries, was invaluable in comparison with any metropolitan before him, and even all of them together. Even today, Sremski Karlovci, the former seat of the
Patriarchate, has a city center built by Patriarch Georgije. In this chapter, the author points out what the life of the Patriarch like was, i.e. his daily church duties, where and for what reason he served the liturgy. Special attention was devoted to the Patriarch's last days and his death, and news about it was published by all the AustroHungarian and Serbian newspapers. Even then, the news shown, depended on the political views of the newspapers owners.

In the Conclusion, the author sums up the attitudes towards Patriarch Georgije Branković and emphasizes his significance once again. All the activities he was involved in were pointed out: in the field of church-school autonomy, as a bishop, patriarch, politician, patron and benefactor. The author states that Branković was not always right, but it was shown that all allegations and frauds his opponents, above all radicals, had accused him of were at the level of the yellow press and untruths, and that his founder's activity could still be seen today. In this way, the author presents an important figure in Serbian history, successfully examining his importance, for the first time in a critical way, contextualizing him in terms of church history, Serbian autonomy and culture. Therefore, this book is recommended to the audience so that they can see the political and cultural scene of the Serbian people in the Austria-Hungary in the last decades of the $19^{\text {th }}$ century and the first decades of the end $20^{\text {th }}$ century.

Nenad Ninković

doi: 10.19090/i.2015.26.202-205

(c) Faculty of Philosophy, Novi Sad, 2015 ISTRAŽIVANJA 26, 202-205

Nikola Samardžić, The Identity of Spain, Belgrade: Admiral Books, 2014, 319 pages.

(Никола Самарџић, Идентитет Шпаније, Београд: Admiral Books, 2014, 319 стр.)

Nikola Samardžić, professor at the University of Belgrade, has re-introduced the liveliness in the Serbian historiographical scene with his new book The Identity of Spain. Familiar with the history of the Mediterranean, Spain, and the Levante, the author delivers, as he himself claims, 
a new book and a new view at problems of Spanish history, especially in the part of the book related to the period after the Second World War, globalization and democratization. A frequent occurrence of the absence of self-criticism, which was common in Serbian historiography, was completely annulled by a particularly sober approach to the disintegration of Yugoslav society in the 1980's.

The entire monograph consists of 16 chapters (without chronological tables and references), clearly and chronologically written, enabling the reader to easily understand the text itself. From the beginning the author defines the geographic, economic and political determinants of Spain, with a brief reference to the time course of the most important events in the two millennia of Spain (The Access, 7-29). The chapter Iberia and Hispania (29-44) begins with the definition of the first identity in the Iberian peninsula and a clear delimitation of geographical, cultural and political models of the ancient history of Spain. With precise, clear data, the author sums up Spanish ancient history by intertwining Carthaginian, Roman, and Iberian models of life, emphasizing the influence of identity and globalists of Roman civilization on the inhabitants of Hispania. A similar approach was also detected in chapter The Kingdom of Visigoths (45-58), which showed the chronological analysis of barbarian invasions, the decline of the Roman influence, identity crises and attempts of sublimation and the delimitation of the old and new elites through the codification of legislation and cultural integration.

The next two chapters, Reconquista (59-79) and Castile and Aragon (79-93), could be viewed as a whole. The Arabian conquest of Spain had an important influence on the identity and the profiling of the Christian, mythical grouping on the basis of Reconquista, the Christian heritage. It also had an influence on a new attitude towards Jews, and on defining frequent expressive conflicts of Christians and Muslims. Often, in two parallel worlds, Muslims and Christians sought to build a new personal identity, trying to preserve their achievements in Castile, Aragon and Leon, or smaller Muslim territories related to a whole range of district feudal lords. The ascent of Castile, its actual or subsequently created Crusader state ideology had a crucial influence on the identity framework of a substantial portion of the Iberian Peninsula. Aragon, on the side of the Mediterranean, was the second important component and the integral part of the identity of the Spanish history. The strengthening of Barcelona, its reputation and financial power, symbolized the second part of profiling politics that would lead to the creation of the empire.

The chapter The First World Empire focuses the reader's attention on the processes resulting from the unification of Castile and Aragon, and the general rise of power of the Spanish Habsburgs with the election of Charles V as the Holy Roman Emperor. The author first vividly and subtlety describes the characters and the physiognomy of Catholic Kings, Isabella of Castile and Fernando of Aragon, emphasizing the ideology of creating a new identity relying on tradition of Reconquista and the new unified state community, which soon grew into a world empire. Also, the author dealt with the problems of Islamic and Hebrew heritage of Spain and the attitude of Catholic kings towards the layered and multidimensional history and culture of Hispania. Very strong local traditions, the provincial fragmentation and rivalry between Fernando and Isabella, Castile and Aragon are presented lively, dynamically and unobtrusively. In a subtle, balanced way, the author portrays all the challenges of the new world empire of Charles $\mathrm{V}$ in the next two chapters (Il Siglo Oro and Epoch of Renewal and Enlightenment, 103-137), and the difficulty of creating a single state and economic unit out of fragmented provinces. The analysis of economic indicators is especially valuable, as well as the rise and fall of Spain from the time of the influx of gold from Central America to the factual recession that largely covered the country since the time of King Philip II. The author covers the analysis of a series of problems which overwhelmed the development of Spain, in both the $16^{\text {th }}$ and the $17^{\text {th }}$ centuries. A variety of problems in the establishment of the central authority, the disappearance of the influence of Spanish Habsburgs, the church issue, the loss of 
the status of a great power and the ultimate collapse of US politics, are presented clearly and extremely rationally without improvisation and wandering. The vitality of the spirit of Spain, enlightenment and renewal of the foundations of economy, seeking rational solutions to completely deliver the country out of the crisis, especially through the prism of the elite (political, landowning, ruling), dominates in the analysis of Spanish history during the $18^{\text {th }}$ century. The emphasis on universality of the Spanish Baroque and a wider analysis of the spirit of provinces, their relationship with the centralist state, introduces the reader to subtleness and details of the complicated reality and necessity of looking deeper into the identity of Spain, especially until the second half of the $18^{\text {th }}$ century. A synthetic spirit of understanding the history of Spain is particularly striking in the aforementioned sections and represents an interesting introduction to the descriptions of the events before the Revolution in France in 1789.

Chapters Dissolution of the Old Regime and Oligarchs of Liberalism (p. 137-169) are full of valuable information and analyses concerning the complicated history of Spain in the period of revolutionary events and the Napoleonic wars in Europe right until the attempt of establishing a new regime in the post-Napoleonic Spain (Europe). The author very vividly compares the dynamic development of the Bourbon-Spain and then the crisis which arose due to the wars which changed the image of well known Europe, and highly unpredictably affected the Spain itself. The famous decisions from 1812 made by Cortes are singled out as the beginning of the formation of the modern Spanish nation, what would later be discussed by the author through the analysis of identity characteristics and conflicts in civil wars which started by Charlist conflicts in the period 1833-1839. Liberal thought, which deeply divided the conservative Spanish society, the rural environment, the old nobility, the church and part of the military structure on the one hand, and citizenship, one part of free thinkers and army on the other hand, is skillfully presented by the author through precisely fitting a sense of identity of Spain into a maelstrom of nationalism, anticlericalism, separatism and Europeanization of the whole society.

The chapter The Fate of Restoration (168-189) in that respect is a continuation of the story about the deep divisions of Spanish society, on all grounds. The First Republic, the period of occurrence of socialist thoughts, the reaction of the Church and the military circles, the old nobility, the failure of complete industrialization, is just the part of the story of Spain presented by the author. The description of the segments of Barcelona, Madrid, the Basque Country, Castile, Catalonia, artistic, cultural and literary milieus of Spain at the turn of the centuries are particularly interesting. Ortega y Gasset, Gaudi, Azaña, then the trauma caused by the loss of the American colonies (1898), brought new ideas about crystallization of a new identity, not only of Spain, but also of Catalonia and the Basque country. The First World War and the following dictatorship of General Primo de Rivera (1923) are described clearly and represent an introduction to the following two chapters, The Second Republic and Epoch of Francoism (189217). The events that would bring Spain back in the epicenter of European developments were certainly related to the restoration of the Republic, its perennial crisis, turn into the dictatorship (totalitarianism) and the outbreak of a civil war, which would divide the European public and cause devastating consequences for Spain itself. The collapse of a democratic society, deferring to the left and right (totalitarian) view of the society led to a three-year civil war, brutal conflicts, reprisals and repression that would mark the process of forming the Spanish identity to this day. The Conservatives, the clergy, part of wealthier citizens, army, led by Francisco Franco on the one side and part of the citizens, workers, supporters of the Communist Party on the other, were engaged for three years in one of the harshest and most ruthless civil wars (1936-1939) in Europe in recent history. One million victims, destroyed cities and industry, devastated villages, permanent and irreconcilable hatred of the warring parties, resulted in passive observation of the events by European democracies, Britain and France, while the fascist Germany and Italy 
actively supported Franco and thus declared the winner. Supporting the Soviet Communists in Spain was both symbolically and financially expensive. Franco's victory was the key element for preventing Spain to more actively participate in the Second World War, but also led to an international isolation until 1953. Gradually opening up towards the European and American markets in the era of technocratic governance symbolized a gradual separation from Francoism during his lifetime. Industrialization, urbanization, and modernization prepared the transformation of the Spanish society after Franco's death (1975). The arrival of Juan Carlos, the formation of a democratic government, and the change of the Constitution 1975-1978, have brought the possibility of transforming Spain into one of countries that aspire to shape the reality of both local and European political situation (The Third Wave, 217-225).

The Challenge of Modern Identities and Spain in the European Union (225-278) are particularly important to the reader as the chapters simultaneously present the problems of the integration of Spanish and Serbian / Yugoslav society. An overview of the contrasts of local individual identities of Catalonia, the Basque Country, the Spanish national identity itself, is written carefully and presented to the readers in a transparent manner. The activities of the terrorist organization ETA, the Catalan nationalists and the attempts of Madrid to effectively define the identity of Spain by overcoming segmentation which was evident and which divided the society itself, are presented dynamically. The Yugoslav reality in the 1980's, the disintegration of Yugoslavia, the disorientation of Yugoslav communist oligarchy to transform society and to provide material progress, followed by a bloody civil war of former Yugoslav republics, are all presented in an genuine analysis by the author and deserve special attention. Foreign and domestic policy of Spain, its rapprochement to the United States, Germany, France, NATO (1982/1986), EEC (1986), the analysis of the Spanish society, the problems faced by technocratic government (since 1962), and the accession of Spain to the European political scene, have played a particularly important part in positioning the society in the Western Balkans in the last 10 years. Particularly impressive is the way in which the author explains the position of Spain in the world of international relations, the challenges of globalization and terrorism from 2001 to 2004 (Al Qaida attacks in Madrid). The identities of Spain (279-282) is the epilogue of the important and interesting monograph by Nikola Samardžić, which analyzes the rich Spanish history, its ups and downs, identity problems and the differences, which have determined the development of Spain and offered a wealth and diversity as an essential priority and political value that has become universal. Therefore the book is recommended to readers as important and necessary for understanding the Yugoslav and Balkan history (especially of the end of the $20^{\text {th }}$ century).

Goran Vasin

doi: 10.19090/i.2015.26.205-208

(C) Faculty of Philosophy, Novi Sad, 2015

ISTRAŽIVANJA 26, 205-208

\section{NARRATIVISM AND INTELLECTUAL HISTORY}

Branko Bešlin, Eugene of Savoy and his era, Novi Sad: Matica srpska, 2014, 655 pages.

(Бранко Бешлин, Евгеније Савојски и његово доба, Нови Сад: Матица српска, 2014, стр. 655)

Access to biographical studies of history with the linguistic turn, especially under the pressure of criticism, has for some time taken on a particular character of relativization. It does not only imply its empirical value, which poststructuralism certainly questions, but the tropological character and the way of giving meaning on the one hand, and conceptual disagreements of the advocates of a "new intellectual history" and the history of ideas on the other hand. Intentional access of positivistic reliance on reconstructive universality, as pointed out by Dominick LaCapra, has generalized the way of approaching the problem, thus losing its scientific value. Writing a biography no longer 